This item was submitted to Loughborough's Research Repository by the author.

Items in Figshare are protected by copyright, with all rights reserved, unless otherwise indicated.

\title{
What is meant by adaptability in buildings?
}

\section{PLEASE CITE THE PUBLISHED VERSION}

http://dx.doi.org/10.1108/F-07-2015-0053

\section{PUBLISHER}

(C) Emerald Group Publishing Limited

\section{VERSION}

AM (Accepted Manuscript)

\section{PUBLISHER STATEMENT}

This work is made available according to the conditions of the Creative Commons Attribution-NonCommercialNoDerivatives 4.0 International (CC BY-NC-ND 4.0) licence. Full details of this licence are available at: https://creativecommons.org/licenses/by-nc-nd/4.0/

\section{LICENCE}

CC BY-NC-ND 4.0

\section{REPOSITORY RECORD}

Pinder, James, Robert Schmidt, Simon Austin, Alistair Gibb, and Jim Saker. 2017. "What Is Meant by Adaptability in Buildings?". Loughborough University. https://hdl.handle.net/2134/20404. 


\title{
What is meant by adaptability in buildings?
}

\author{
James Pinder ${ }^{1}$, Rob Schmidt III ${ }^{1}$, Simon Austin ${ }^{1}$, Alistair Gibb ${ }^{1}$ and Jim Saker ${ }^{2}$ \\ ${ }^{1}$ School of Civil and Building Engineering, Loughborough University \\ ${ }^{2}$ School of School of Business and Economics, Loughborough University
}

\begin{abstract}
Purpose

Despite being a common term in the literature, there is little agreement about what the word 'adaptability' means in the context of the built environment and very little evidence regarding practitioners' understanding of adaptability. This paper therefore examines what practitioners in the building industry mean when they talk about 'adaptability'.
\end{abstract}

\section{Design/methodology/approach}

This study adopted a qualitative approach, involving 82 unstructured face-to-face interviews with practitioners from a range of professional disciplines in the construction industry, including architects, engineers, facilities managers, property agents and planners. The interview transcripts were coded inductively in order to identify themes in the qualitative data.

\section{Findings}

The interview data revealed a wide range of perspectives on adaptability, particularly regarding terminology, the meanings practitioners associate with adaptability and the way in which these meanings are communicated to others in the industry. The applied meaning of adaptability varied depending on context.

\section{Practical implications}

Conflicting language, and different interpretations of adaptability, is a potential barrier to the development of adaptable buildings. A clearer articulation of the meaning of adaptability (particularly by clients) during briefing and design could give rise to a more appropriate level of adaptability in the built environment.

\section{Originality/value}

This study has addressed a gap in the existing literature, by foregrounding the voices of industry practitioners and exploring their (sometimes very different) interpretations of adaptability in buildings.

Keywords: Change; clients; communications; briefing; flexibility; stakeholders. 


\section{Introduction}

Adaptability has long been considered to be a desirable characteristic in the built environment. For instance, in the 1950s, Lynch (1952) discussed adaptability in the context of urban design and planning, and in the 1960s Weeks (1965) made the case for more adaptable hospital buildings. In the decades since, adaptability has been promoted as a design strategy in a wide range of building types, including offices, housing and healthcare. Leaman et al. (1998) suggested that the word 'adaptability' is “... now commonplace in the vocabulary of briefing, building design and building management”. But what do practitioners in the building industry mean when they talk about adaptability? And to what extent is there a shared understanding of adaptability across the industry? Such questions are pertinent because, if the literature is anything to go by, there is still considerable uncertainty concerning the meaning of adaptability in the context of the built environment.

This paper explores the above questions using data from interviews with 82 (predominantly UK-based) practitioners in the building industry including architects, engineers, facilities managers, property agents and planners. It begins by examining how adaptability is defined in the built environment literature and by identifying commonalities that link definitions. In the second part it describes the interview research and explores the themes arising from analysis of the data. This paper concludes by considering how a clearer articulation of the meaning of adaptability during the briefing and design process might result in a more appropriate level of adaptability in the built environment.

\section{Background}

The existing literature on adaptability in buildings is very diverse, encompassing a variety of disciplines, including architecture, engineering, facilities management (FM) and planning, and a wide range of building types. This diversity has given rise to a broad range of perspectives on adaptability, but it also means that adaptability remains very much a 
misconstrued concept: the word means (or signifies) different things to different people. Friedman (2002, p.1) suggested that "Misconceptions about adaptability are the outcome of the term's many definitions and interpretations" and this was certainly evident when reviewing the literature. 'Adaptability' has become a "buzzword” (Carthey et al., 2011, p.89) - frequently used, but much misunderstood.

The concept of change is the most common thread that runs through definitions of adaptability in the literature, irrespective of building type or sector (Table 1). However, this still leaves room for interpretation as to what type of change is being described by each author: for Carthey et al. (2011) the word 'adaptability' signals a change of use; Friedman, (2002) and Arge (2005) interpret it as being just about changes within the existing use type; and Ellison and Sayce (2007) see it as encompassing both types of change. Nevertheless, three types of change - of use, physical layout and size - are referred to consistently throughout the literature, despite differences in terminology. Some authors also make a distinction between: the speed of change (fast or slow) (Blyth and Worthington, 2000); the magnitude of change (small or large) (Leaman et al., 1998; Russell and Moffatt, 2001); or the nature of change (passive accommodation or active response) (Schneider and Till, 2007; Blakstad, 2001). Friedman's (2002) definition represents a departure from other definitions in Table 1 , in that adaptability is about facilitating a fit between a building and its users. This might be reflective of the fact that he was focusing on homes, which are often designed without the knowledge of who will be living in them.

Definitions of adaptability in the literature also differ in the sense that some authors place an emphasis on either the motives (triggers) for and/or the outcomes (impact) of adaptability (Table 1). In some cases, authors refer to the broader causes or triggers behind the need for adaptability, for instance in terms of changing technologies or social processes (Schneider \& Till, 2007), whereas in others cases the focus is on the more specific motives for adaptability, 
such as the need to accommodate "changing occupier demand" (Ellison and Sayce, 2007) or “meet changing user or owner needs" (Arge, 2005). Similarly, definitions of adaptability vary with some (Leaman et al., 1998) emphasising the short-term (or immediate) outcomes or impacts of adaptability (e.g. a building being easier and less costly to adapt) and others (Addis and Shouten, 2004) focusing on the longer-term consequences of these shorter-term impacts (e.g. extending the useful life of a building).

The specific motives and short-term outcomes discussed in the literature often reflect distinct understandings of how to accommodate that need, such as spatial-based or component-based solutions (Schneider \& Till, 2007); and active or passive responses (Leaman et al., 1998). Divergence also occurs across sector specific literature, with some authors (e.g. Arge, 2005; Pressler, 2006) making reference to particular design solutions (e.g. bed pods and interstitial floors for healthcare facilities or moveable desks and taller storey heights for offices). Interestingly, the distinctions articulated in the literature are not necessarily in tension with each other - rather they are context specific.

Confusion about the meaning of adaptability is exacerbated by the fact that authors use terminology (or signifiers) in different ways. For instance, while some authors treat the terms 'adaptability' and 'flexibility' as synonyms, others make a distinction between the two concepts, but often in conflicting ways (Table 2). Whereas Leaman and Bordass (2004, p.154) define “... flexibility as primarily about short-term changes and adaptability about less frequent but often more dramatic ones”, Schneider and Till (2005, p.157) describe adaptability as being “capable of different social uses” and flexibility as being "capable of different physical arrangements”. Arge (2005) adopted an altogether different approach, categorising flexibility (enabling changes by modifying the properties of the building) as a sub-set of adaptability, alongside generality (enabling changes without modifying the properties of the building) and elasticity (the ability to extend or partition a building). 
Table 1: Definitions of adaptability (from literature)

\begin{tabular}{|c|c|c|c|c|c|}
\hline Source & $\begin{array}{l}\text { Building } \\
\text { type/ } \\
\text { sector }\end{array}$ & Definition & $\begin{array}{l}\text { Type of change } \\
\text { (WHAT) }\end{array}$ & Design tactics (HOW) & Motives/outcomes (WHY) \\
\hline $\begin{array}{l}\text { Ellison \& } \\
\text { Sayce (2007) }\end{array}$ & Offices & $\begin{array}{l}\text { The building's ability to meet changing } \\
\text { occupier demand into the future }\end{array}$ & $\begin{array}{l}\text { Configuration of } \\
\text { space, interior finishes, } \\
\text { space ratios and use }\end{array}$ & $\begin{array}{l}\text { Structural design, type of } \\
\text { services and the quality of } \\
\text { finishes }\end{array}$ & $\begin{array}{l}\text { Accommodate changing } \\
\text { user demands, new user or } \\
\text { new use }\end{array}$ \\
\hline Arge (2005) & Offices & $\begin{array}{l}\text { The ability to meet changing user or } \\
\text { owner needs in three ways: without } \\
\text { changing the properties of the building, by } \\
\text { changing the properties of the building } \\
\text { easily, or by extending or partitioning the } \\
\text { building as needed. }\end{array}$ & $\begin{array}{l}\text { Configuration of space } \\
\text { and scale of building }\end{array}$ & $\begin{array}{l}\text { Without changing the } \\
\text { properties of the building, by } \\
\text { changing the properties of } \\
\text { the building easily, or by } \\
\text { extending or partitioning the } \\
\text { building as needed }\end{array}$ & $\begin{array}{l}\text { Meet changing user or } \\
\text { owner needs }\end{array}$ \\
\hline $\begin{array}{l}\text { Schneider \& } \\
\text { Till (2007) }\end{array}$ & Housing & $\begin{array}{l}\text { Can adjust to changing needs and } \\
\text { patterns, both social and technological. } \\
\text { These changes may be personal } \\
\text { (expanding family), practical (i.e. onset of } \\
\text { old age), or technological (i.e. updating of } \\
\text { services). }\end{array}$ & $\begin{array}{l}\text { Configuration of space } \\
\text { and scale of building }\end{array}$ & $\begin{array}{l}\text { Spatial organisation, } \\
\text { circulation patterns, room } \\
\text { designations, } \\
\text { joining/dividing rooms, equal } \\
\text { rooms, adjustable furniture, } \\
\text { construction method }\end{array}$ & $\begin{array}{l}\text { Adjust to changing needs } \\
\text { and patterns, social and } \\
\text { technological }\end{array}$ \\
\hline $\begin{array}{l}\text { Carthey et } \\
\text { al. (2011) }\end{array}$ & Healthcare & $\begin{array}{l}\text { Plan and implement an organized system } \\
\text { whereby a health facility can fulfil its long } \\
\text { term potential by being able to respond to } \\
\text { the necessity of future changes of purpose } \\
\text { or use. }\end{array}$ & $\begin{array}{l}\text { Configuration of space } \\
\text { and interior finishes }\end{array}$ & $\begin{array}{l}\text { Universal room design, } \\
\text { standardised rooms, shell } \\
\text { spaces, interstitial floors, } \\
\text { modular design, soft spaces }\end{array}$ & $\begin{array}{l}\text { Respond to future changes } \\
\text { of use }\end{array}$ \\
\hline $\begin{array}{l}\text { Blyth \& } \\
\text { Worthington } \\
\text { (2010) }\end{array}$ & Offices & $\begin{array}{l}\text { Larger scale changes over longer periods } \\
\text { of time (long-term and strategic) - shape } \\
\text { and size of room (accommodate a variety } \\
\text { of different functions over time) }\end{array}$ & $\begin{array}{l}\text { Configuration of space } \\
\text { and building use }\end{array}$ & $\begin{array}{l}\text { Shape and size of room, } \\
\text { floor-to-floor heights, service } \\
\text { strategy, natural ventilation, } \\
\text { structural grid, space } \\
\text { planning }\end{array}$ & $\begin{array}{l}\text { Accommodate a variety of } \\
\text { different functions over } \\
\text { time }\end{array}$ \\
\hline
\end{tabular}




\begin{tabular}{|c|c|c|c|c|c|}
\hline Source & $\begin{array}{l}\text { Building } \\
\text { type/ } \\
\text { sector }\end{array}$ & Definition & $\begin{array}{l}\text { Type of change } \\
\text { (WHAT) }\end{array}$ & Design tactics (HOW) & Motives/outcomes (WHY) \\
\hline $\begin{array}{l}\text { Russell and } \\
\text { Moffatt } \\
\text { (2001) }\end{array}$ & Generic & $\begin{array}{l}\text { The capacity of buildings to accommodate } \\
\text { substantial change }\end{array}$ & $\begin{array}{l}\text { Configuration of } \\
\text { space, building } \\
\text { performance scale of } \\
\text { building, and building } \\
\text { use }\end{array}$ & $\begin{array}{l}\text { Durability, service access, } \\
\text { simplicity, component } \\
\text { separablility, redundant } \\
\text { structure, plan depth, floor to } \\
\text { floor heights }\end{array}$ & $\begin{array}{l}\text { Accommodate substantial } \\
\text { change }\end{array}$ \\
\hline $\begin{array}{l}\text { Friedman } \\
(2002)\end{array}$ & Residential & $\begin{array}{l}\text { Provides occupants with forms and means } \\
\text { that facilitate a fit between their space } \\
\text { needs and the constraints of their homes } \\
\text { either before or after occupancy. }\end{array}$ & $\begin{array}{l}\text { Space needs/ home } \\
\text { constraints }\end{array}$ & $\begin{array}{l}\text { Home’s dimensions, access } \\
\text { and circulation, façade } \\
\text { design, growth, structure and } \\
\text { assembly }\end{array}$ & Meet changing user needs \\
\hline $\begin{array}{l}\text { McGregor } \\
\text { (1994) }\end{array}$ & Offices & $\begin{array}{l}\text { Ensuring the environment, both internal } \\
\text { and external, can be configured and re- } \\
\text { configured to suit different building users, } \\
\text { their changing needs, works processes and } \\
\text { layouts. }\end{array}$ & $\begin{array}{l}\text { (Re)configure internal } \\
\text { and external } \\
\text { environment }\end{array}$ & $\begin{array}{l}\text { Organisational strategies } \\
\text { (shared facilities, labour } \\
\text { pooling, central overheads), } \\
\text { asset strategies (lease } \\
\text { lengths, return periods) }\end{array}$ & $\begin{array}{l}\text { Accommodate different } \\
\text { building users' needs, work } \\
\text { processes and layouts }\end{array}$ \\
\hline $\begin{array}{l}\text { Pressler } \\
(2006)\end{array}$ & Health care & $\begin{array}{l}\text { Areas that can be planned, designed and } \\
\text { constructed in a way that allows the } \\
\text { facility to accommodate future change. } \\
\text { These changes include adaptations in } \\
\text { operational models, site and facility } \\
\text { design to accommodate future expansion } \\
\text { of services. }\end{array}$ & $\begin{array}{l}\text { Configuration of } \\
\text { furniture and } \\
\text { equipment, space and } \\
\text { building performance }\end{array}$ & $\begin{array}{l}\text { Operational and space } \\
\text { standards, soft space, } \\
\text { circulation, size and shape of } \\
\text { room, }\end{array}$ & $\begin{array}{l}\text { Accommodate future } \\
\text { change, expansion of } \\
\text { services. }\end{array}$ \\
\hline $\begin{array}{l}\text { Leaman et } \\
\text { al. (1998) }\end{array}$ & Generic & $\begin{array}{l}\text { Greater potential for larger-scale changes } \\
\text { over longer periods, without cutting off } \\
\text { crucial options or making things } \\
\text { unnecessarily costly or complicated - } \\
\text { adaptability involves additional } \\
\text { knowledge of context, purpose, and } \\
\text { application. }\end{array}$ & $\begin{array}{l}\text { Configuration of space } \\
\text { and building } \\
\text { performance }\end{array}$ & $\begin{array}{l}\text { Technology reliant, building } \\
\text { layers, behavioural, good } \\
\text { daylight, minimise } \\
\text { specialised space, simplicity }\end{array}$ & $\begin{array}{l}\text { Accommodate potential for } \\
\text { large-scale changes }\end{array}$ \\
\hline
\end{tabular}




\begin{tabular}{|l|l|l|l|l|}
\hline Source & $\begin{array}{l}\text { Building } \\
\text { type/ } \\
\text { sector }\end{array}$ & Definition & $\begin{array}{l}\text { Type of change } \\
\text { (WHAT) }\end{array}$ & Design tactics (HOW) \\
\hline $\begin{array}{l}\text { Addis and } \\
\text { Shouten } \\
\text { (2004) }\end{array}$ & Generic & $\begin{array}{l}\text { A building that has been designed with } \\
\text { thought of how it might be easily altered }\end{array}$ & & Easily altered, prolong its \\
\hline
\end{tabular}


Table 2: Six types of adaptability in buildings (adapted from Schmidt et al., 2010; p.7)

\begin{tabular}{|l|l|l|l|}
\hline $\begin{array}{l}\text { Type of } \\
\text { adaptability }\end{array}$ & Type of change & Examples & Frequency of change \\
\hline Adjustable & $\begin{array}{l}\text { Changing the } \\
\text { configuration of an } \\
\text { individual setting }\end{array}$ & Sit-stand desks in offices & $\begin{array}{l}\text { Very high (e.g. every day, } \\
\text { week, month) }\end{array}$ \\
\hline Versatile & $\begin{array}{l}\text { Changing the dimensions } \\
\text { of a space }\end{array}$ & Moveable partitions & High (every 1-5 years) \\
\hline Refitable & $\begin{array}{l}\text { Changing the performance } \\
\text { of a building }\end{array}$ & 'Plug and play' services & $\begin{array}{l}\text { Moderate (e.g. every 5-15 } \\
\text { years) }\end{array}$ \\
\hline Convertible & $\begin{array}{l}\text { Changing the use/ } \\
\text { function of a building }\end{array}$ & $\begin{array}{l}\text { Floor to soffit heights that } \\
\text { allow office to residential } \\
\text { conversion }\end{array}$ & $\begin{array}{l}\text { Low (once or twice in a } \\
\text { building's lifetime) }\end{array}$ \\
\hline Scalable & $\begin{array}{l}\text { Changing the size of a } \\
\text { building }\end{array}$ & $\begin{array}{l}\text { Over-sized foundations to } \\
\text { accommodate extensions }\end{array}$ & $\begin{array}{l}\text { Low (once or twice in a } \\
\text { building's lifetime) }\end{array}$ \\
\hline Moveable & $\begin{array}{l}\text { Changing the location of a } \\
\text { building }\end{array}$ & $\begin{array}{l}\text { Modular pods that enable } \\
\text { disassembly/ } \\
\text { deconstruction }\end{array}$ & Very low (rarely) \\
\hline
\end{tabular}

Schmidt et al. (2010) build upon and consolidate these earlier definitions by defining six types of adaptability that relate to the type and frequency of changes that occur in buildings (Table 3).

Table 3: Distinctions between 'adaptability' and 'flexibility' in buildings (from literature)

\begin{tabular}{|l|l|l|}
\hline Source & Adaptability & Flexibility \\
\hline Blyth and Worthington (2000) & $\begin{array}{l}\text { Larger scale changes over } \\
\text { longer timescales }\end{array}$ & $\begin{array}{l}\text { Quick changes, involving little } \\
\text { effort or cost }\end{array}$ \\
\hline Schneider and Till (2005) & Capable of different social uses & $\begin{array}{l}\text { Capable of different physical } \\
\text { arrangements }\end{array}$ \\
\hline Leaman and Bordass (2004) & $\begin{array}{l}\text { Infrequent, long-term, high } \\
\text { magnitude changes }\end{array}$ & $\begin{array}{l}\text { Frequent, short-term, low } \\
\text { magnitude changes }\end{array}$ \\
\hline Groak (1992) & $\begin{array}{l}\text { Territorial change (social } \\
\text { aspects) }\end{array}$ & $\begin{array}{l}\text { Technological change (physical } \\
\text { aspects) }\end{array}$ \\
\hline
\end{tabular}


We believe this classification provides a more nuanced framework for thinking about the types of change that occur in buildings and how these can be accommodated through design. Distinctions between adaptability types are offered by other sources in the literature, but the six types articulated by Schmidt et al. are arguably the most comprehensive. Their classification is used later in this paper to help make sense of and delineate the interview data. Although there is a broad body of literature on adaptability and its meaning, there has been very little research into how practitioners in the building industry understand the concept. One of the few studies to shed light on this issue was by Ellison and Sayce (2007), who held focus groups with property (real estate) agents in the United Kingdom (UK). Their research suggested that commercial property agents had a very narrow interpretation of adaptability, relating primarily to the flexibility of internal spaces, and that other forms of adaptability, such as the capacity to accommodate changes of use, were not factored into valuations (appraisals). This finding is important because, as Schiellerup and Gwilliam (2009) point out, property agents play an important role in informing the decisions of other stakeholders in the building industry, influencing amongst other things the specifications to which new buildings are designed and constructed.

Research undertaken in Norway by Olsson and Hansen (2010, p.35) provided an insight into how practitioners in healthcare building projects communicate their understanding of adaptability to each other. They found that project stakeholders “...either used different terminology or the same terminology with different meanings. Each of the projects tended to develop its own terminology”. This apparent lack of a congruent language when communicating about adaptability is interesting because it may ultimately lead to misunderstandings about project objectives during the briefing and design process, particularly given stakeholders' reliance on the physical brief (e.g. see Chandra and Loosemore, 2011). 
Three main conclusions can be drawn from the existing literature on adaptability:

i. there is a lack of consensus about the meaning of adaptability: while the notion of accommodating change over time is a common thread in the literature, adaptability remains very much a misconstrued concept, in part because the meaning of adaptability appears to be context specific;

ii. it is difficult to divorce the 'what' of adaptability from the 'why' and 'how' of adaptability - to varying degrees, definitions in the literature cut across these three facets of adaptability (Figure 1) and tend to be context specific; and

iii. there is very little evidence regarding practitioners' understanding of adaptability, despite suggestions that the word is in common parlance.

We therefore focus on this gap in knowledge, exploring to what extent practitioners have a shared understanding of adaptability in buildings.

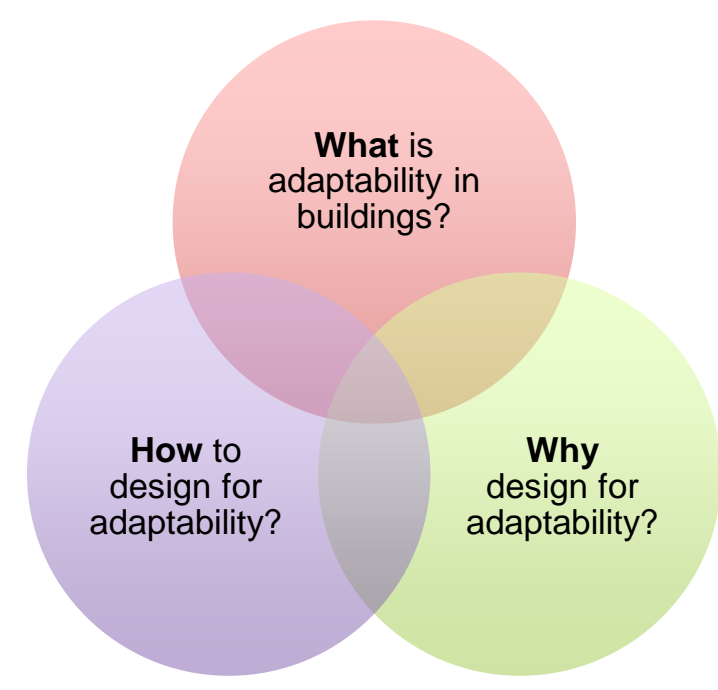

Figure 1: Overlaps in the meaning of adaptability

\section{Research methods}

The aim of this study was explore what industry practitioners mean when they talk about adaptability in buildings. The authors adopted an inductive approach in which knowledge and 
meaning are socially constructed and situated in practice (e.g. see Berger and Luckmann, 1966). Reflecting this approach, the authors undertook unstructured face-to-face qualitative interviews with practitioners from a range of professional disciplines in the construction industry (Table 4). Industry practitioners were defined as people that are engaged in the building development process and influence how buildings are designed and constructed (Olander, 2007). Gaining a multidisciplinary perspective on adaptability was important because professional background and situated practices can influence how one views the world (Fischler, 1995).

The data comprised transcripts from 82 interviews conducted over a two year period. The interviews were part of an independently funded study into adaptability, involving a multidisciplinary team of researchers with backgrounds in architecture, civil engineering, sociology, construction management, FM, and business and management. Interviews were the most efficient and practical way of accessing the views of practitioners, being a tried and tested method for exploring meaning and unpacking abstract concepts, in a range of disciplines. Most of the interviews were part of case study research, although case study findings are not reported in this paper for reasons of brevity and relevance.

Interviewees were sampled purposively (theoretical sampling) because this enabled the selection of individuals that would be informative to the research, based upon recommendations from industry contacts or prior knowledge of their work derived from information available in the public domain. Sampling was driven by the research questions, selecting cases with the particular phenomenon (adaptability) in mind and for the likelihood that they will offer theoretical insight (Eisenhardt and Graebner, 2007). Although the authors make no claims about the representativeness of the sample, they did sample for maximum variation by interviewing practitioners from a diverse range of sectors. The majority of interviewees resided and practised in the UK - a fact that is reflected in the examples cited in 
the findings - however when the opportunity arose practitioners in other countries, including Japan and the United States, were interviewed in order to explore whether the meaning of adaptability varies across cultures. Architects constitute almost half of the sample, primarily because they were generally the first point of contact when learning more about the case study buildings - again this is, to some extent, reflected in the examples cited below. Around one quarter of interviewees worked on the client-side of the industry: a mix of owneroccupiers, property developers, facilities managers or in-house specialists (engineers, project managers and an environmental manager). The remainder were on the supply-side (architects, quantity surveyors, engineers etc...) or intermediaries (local authority planners and valuers/agents). In most cases, interviewees needed very little prompting and talked extensively about their experiences and understanding of adaptability, providing a rich narrative for analysis.

Table 4: Number of interviews, by discipline

\begin{tabular}{|c|c|}
\hline Professional discipline & No. interviewees \\
\hline Architect & 36 \\
\hline Engineer & 5 \\
\hline Environmental manager & 1 \\
\hline Facilities/estates manager & 3 \\
\hline Planner & 5 \\
\hline Client/developer & 14 \\
\hline Project manager & 10 \\
\hline Quantity surveyor & 1 \\
\hline Urban designer & 2 \\
\hline Valuer/agent & 5 \\
\hline Total & $\mathbf{8 2}$ \\
\hline
\end{tabular}


The interviews were recorded with the consent of the interviewees and transcribed prior to analysis. The interview transcripts were then coded inductively in order to identify themes in the qualitative data. The data were coded independently by two of the authors, thereby providing a layered approach to the analysis and reducing the likelihood that themes or issues were overlooked, since different people - with different values, assumptions and experiences - will inevitably see different things in the interview data (Richards and Morse, 2012). One researcher followed Dubois and Gadde’s (2002) approach of systematic combining in which an initial framework was generated to articulate any preconceptions, while the other followed Strauss and Corbin’s (1998) grounded theory approach without any initial framework. In both cases, the transcriptions were read thoroughly and thematically coded. Thematic tables were generated and underwent multiple iterations of review (interpretation and reflection) as part of the continuous data collection process (Richards and Morse, 2012). The two approaches were kept discrete until the final stage of conceptualising the theory. The two similar (yet different) approaches were used to corroborate the qualitative findings (triangulation) and to assure a comprehensive approach was taken to exploring the research problem. The intent of triangulation was not to replicate results but to obtain complementary findings that strengthen the results (Morse, 1991).

The authors did not count the frequency with which interviewees referred to particular concepts because they felt that this would have ignored the context in which interviewees used a particular word and the meanings they associate with it, thereby misrepresenting the voices of the people being studied (Pratt, 2008). Silverman (2000, p.184) argued that "Without a theoretical rationale behind the tabulated categories, counting only gives a spurious validity to research" - there was no theoretical rationale in this research, because the authors were more interested in the congruency and diversity of terms (concepts), rather than the frequency with which an individual term was used. 


\section{Discussion of findings}

Coding of the interview transcripts revealed a range of perspectives but three themes emerged that relate primarily to the 'what', rather than the 'why' or 'how', of adaptability (Figure 1), namely:

1. Terminology (signifiers) - the words, including synonyms, antonyms and metaphors, that practitioners use when talking about adaptability in buildings;

2. Meaning (signals) - the denotations and connotations that practitioners use when explaining what adaptability means to them; and

3. Briefing (communication) - how clients articulate the need for adaptability in their buildings and how other practitioners interpret this need.

\subsection{Terminology (signifiers)}

Interviewees used a wide variety of words when talking about adaptability in buildings, including resilient, indeterminate, future-proofed, flexible, unfinished, agile, durable, longlasting, modular, intolerant, specific, ungenerous and fixed. In some cases these terms were used as synonyms or antonyms for adaptability (the what), in others they were used to describe design strategies (the how) or the motives behind adaptability (the why). Many interviewees used the word 'flexibility' as a synonym for adaptability; that is to say, they did not distinguish between ‘adaptability’ and ‘flexibility’ as separate concepts, but tended to use the latter as a means to achieve the former (i.e. if it's flexible, it's adaptable). This reflects the way that these two words are often used in the literature, with flexibility being the more frequently used of the two terms.

Interviewees also used other words that described aspects or qualities of adaptability, such as future-proofing:

"I think adaptability from my perspective is future-proofing so it's really to develop a scheme that has the flexibility to meet retailers' needs in the future but 
also customer needs of the future, the people that go into the shops. So it's really

flexibility within the building to meet future requirements" (Engineer \#1)

Some interviewees associated 'adaptability' in buildings with a tolerance for change and a capacity "to be knocked about” (Architect \#1). Interviewees used terms such as "knocking through", "ripping out”, “smashing it around" or "kicking about” when talking about adaptability in buildings, even though this seems to run counter to the notion of nondestructive change that is sometimes put forward in the literature on adaptability. This may be a reflection of the fact that many interviewees viewed resilience, durability and robustness as key facets of adaptability.

The phrase 'long-life/loose-fit' was used repeatedly in the interviews a strategy that is synonymous with adaptability. This reflects the way in which many architects and engineers aspired to design for adaptability: by creating buildings that are both durable (long-life) and have generous space provision (loose-fit). Interviewees also used a range of antonyms to describe the absence or lack of adaptability in buildings. For example, one architect (Architect \#2) talked about 'intolerant' and 'ungenerous' buildings that are unable to accommodate change, and another referred to "fixed immutable architecture" (Architect \#3).

Some interviewees used metaphors to articulate their thoughts about adaptability in buildings. According to Froggatt (1998, p.332) metaphors are important because "The metaphors and images present within a given society reveal the fundamental values and assumptions underpinning that culture". For instance one architect summed up the notion of 'loose-fit' buildings by suggesting that:

“... it's almost like people actually, you know, sometimes, you know, if you're sitting at a dinner party and some people are so focused, but actually the people you want to be friends with usually are the ones that are, kind of, relaxed and easy going, you know, they don't need four glasses of wine to sort themselves out, not like me, you know, and they're at ease with things and that's what building should be" (Architect \#4) 
Another architect used the metaphor of a suit when discussing the tension between adaptability and specificity in buildings, arguing that tailor-made suits feel good and make people look elegant, whereas "nobody ever looks good in" a one-size-fits-all off the rack suit (Architect \#5).

Interviewees sometimes referred to historic building types to represent their understanding of what adaptability is, for instance historic Victorian warehouses, Georgian terrace housing, big box retail and 1960s office buildings. These references were described through their physical and spatial characteristics (binding the how to the what), such as robustness, open floor plans, tall floor-to-floor heights and large windows. One structural engineer argued that:

“... you can go into an old mill building and you can knock it around an enormous amount before it gets to be serious. You go into a modern building and you start knocking it about and, very soon, it'll go unstable because it's been designed to a much tighter limit” (Engineer, \#2)

In contrast, contemporary buildings, designed for very specific purposes, heavily serviced and built using modern methods of construction, were considered by some interviewees to be the antithesis of adaptability. Such buildings were associated with unproven techniques, synthetic materials, monolithic construction, optimised efficiency, calculated redundancy, integrated components, short-life spans and poor workmanship. However, the danger of using a building type or a metaphor when talking about adaptability is that people often do not always share the same frame of reference, which can contribute to misunderstandings.

\subsection{Meaning (signals)}

The meanings that interviewees attached to the word 'adaptability' were very varied. For some interviewees, adaptability was more about accommodating specific types of change ("different ways of tenanting the building", "the scope to extend", "different space planning arrangements"), whereas for others it was about a more open-ended outcome (to "stand the test of time" or "last the course"). Most of the meanings that were discussed in the 
interviews were building-centric, that is to say they described the ways in which a building can adapt. However, some interviewees also ascribed person-centric meanings to adaptability; in other words, they were thinking about adaptability in terms of how users, rather than the building, can accommodate change by performing particular actions, for instance by moving furniture or changing the use of a room.

Table 5 illustrates the differences in meaning of adaptability associated with six sectors (building use types). The sectors are stratified based on the types of changes associated with each use class. The third column (from the left) highlights how those meanings are translated into the adaptability types used by Schmidt et al. (2010). The meanings that practitioners attached to adaptability tended to diverge by sector rather than discipline, often reflecting clients' priorities or market norms in a particular sector - where overlap existed regarding the meaning of adaptability at a high-level, differentiation occurred regarding the design tactics (how) and motivations (why). For instance, practitioners operating in the UK retail sector tended to distinguish between pre- and post-completion adaptability, the former being about enabling changes to the building during construction and the latter being about accommodating the requirements of a wide range of retailers. Their emphasis on precompletion adaptability was a reflection of the long lead times that can occur in the development of large retail schemes, during which time market conditions and retailers' requirements may change. These practitioners did not tend to equate adaptability with change of use, largely because planning restrictions tend to preclude such changes in large-scale retail schemes in the UK. 
Table 5: Meaning of adaptability in different sectors (from interviews)

\begin{tabular}{|c|c|c|c|c|}
\hline Sector & $\begin{array}{l}\text { Type of } \\
\text { change }\end{array}$ & $\begin{array}{l}\text { Type of } \\
\text { adaptability }\end{array}$ & Design tactics & Motive/Outcome \\
\hline Retail & $\begin{array}{l}\text { Configuration } \\
\text { of space }\end{array}$ & $\begin{array}{l}\text { Versatile, } \\
\text { Refitable }\end{array}$ & $\begin{array}{l}\text { Separation of tenant infill within landlord } \\
\text { framework, combine retail units, grid } \\
\text { coordination, planning grid, framed structure, } \\
\text { intermediate component, reversible connection, } \\
\text { standard product, general surplus capacity }\end{array}$ & $\begin{array}{l}\text { Accommodate different tenants and changing } \\
\text { tenant needs }\end{array}$ \\
\hline \multirow[t]{2}{*}{ Healthcare } & $\begin{array}{l}\text { Configuration } \\
\text { of equipment }\end{array}$ & Adjustable & $\begin{array}{l}\text { Equipment that can be moved or configured easily, } \\
\text { adjustable furniture, fixtures, equipment }\end{array}$ & $\begin{array}{l}\text { Accommodate different services for patients, } \\
\text { different types of patients and user customisation }\end{array}$ \\
\hline & $\begin{array}{l}\text { Building } \\
\text { Performance }\end{array}$ & Refitable & Easy separation of components, equipment & Accommodates new technologies \\
\hline \multirow[t]{3}{*}{ Office } & $\begin{array}{l}\text { Configuration } \\
\text { of space }\end{array}$ & Versatile & $\begin{array}{l}\text { Moveable furniture, equipment and partitions, } \\
\text { common space, hot-desking, undefined space, } \\
\text { variety of finishes/ furniture, open space, wide } \\
\text { circulation }\end{array}$ & $\begin{array}{l}\text { Accommodate different activities (size, formality) } \\
\text { and tenant customisation }\end{array}$ \\
\hline & Interior finish & Refitable & $\begin{array}{l}\text { Market standard (e.g. Grade A), shell \& core } \\
\text { construction, custom finishes }\end{array}$ & $\begin{array}{l}\text { Accommodate a range of tenants (different spatial } \\
\text { demands) }\end{array}$ \\
\hline & Building use & Convertible & $\begin{array}{l}\text { Shallow plan depth, multiple cores, divisible } \\
\text { services }\end{array}$ & Accommodate a shift in market (residential, hotel) \\
\hline Education & $\begin{array}{l}\text { Configuration } \\
\text { of space }\end{array}$ & $\begin{array}{l}\text { Adjustable, } \\
\text { Versatile }\end{array}$ & $\begin{array}{l}\text { Adjustable/moveable furniture/equipment, close } \\
\text { off/open up spaces, variety of room sizes, spatial } \\
\text { adjacencies }\end{array}$ & Accommodate a variety of teaching environments \\
\hline
\end{tabular}




\begin{tabular}{|l|l|l|l|l|}
\hline Sector & $\begin{array}{l}\text { Type of } \\
\text { change }\end{array}$ & $\begin{array}{l}\text { Type of } \\
\text { adaptability }\end{array}$ & Design tactics & Motive/Outcome \\
\hline & Building use & Convertible & $\begin{array}{l}\text { Secondary entrance, separable space (security, } \\
\text { services) }\end{array}$ & $\begin{array}{l}\text { Secondary uses during non-core hours (evening, } \\
\text { weekends, summer) }\end{array}$ \\
\hline Residential & $\begin{array}{l}\text { Configuration } \\
\text { of space }\end{array}$ & Versatile & $\begin{array}{l}\text { Open plan, moveable furniture, spatial } \\
\text { adjacencies, fixed versus flexible space }\end{array}$ & $\begin{array}{l}\text { Accommodate a variety of room layouts and } \\
\text { activities }\end{array}$ \\
\cline { 2 - 5 } & Size of home & Scalable & $\begin{array}{l}\text { General surplus capacity, extendable circulation, } \\
\text { leftover/ underused space, framed structure }\end{array}$ & $\begin{array}{l}\text { Allow for expansion/shrinkage to accommodate } \\
\text { changes in family demographics/lifestyles }\end{array}$ \\
\cline { 2 - 5 } & Interior finish & Refitable & $\begin{array}{l}\text { Unfinished space, bare bones (infrastructure), } \\
\text { custom finishes, market standard, shell and core } \\
\text { construction }\end{array}$ & $\begin{array}{l}\text { Accommodate a range of users and customisation } \\
\text { (DIY) }\end{array}$ \\
\hline \multirow{2}{*}{ Theatre } & $\begin{array}{l}\text { Configuration } \\
\text { of space }\end{array}$ & $\begin{array}{l}\text { Adjustable, } \\
\text { Versatile }\end{array}$ & Moveable furniture, equipment and partitions & $\begin{array}{l}\text { Accommodates different performance } \\
\text { configurations (set, audience, lighting, etc.) }\end{array}$ \\
\cline { 2 - 5 } & Building use & Convertible & $\begin{array}{l}\text { Windows with shades (dark/light), additional } \\
\text { doors (separate access), moveable furniture, } \\
\text { equipment, partitions, neutral colours }\end{array}$ & $\begin{array}{l}\text { Accommodates uses (secondary uses), e.g. } \\
\text { teaching or community events }\end{array}$ \\
\hline
\end{tabular}




\subsection{Briefing (communication)}

The interviews provided a fascinating insight into how clients articulate a need for adaptability during the briefing process and how supply-side stakeholders interpret this need. Figure 2 contains four archetypal client groups, which were identifiable from the interview data. The clients in the first group (Type A) were typically either less experienced clients or clients for whom adaptability was not on their 'radar', perhaps because the short-term or stable nature of their business meant that adapting their buildings in the future was not deemed to be an issue. In such cases supply-side stakeholders often saw it as their professional responsibility to "... open up the client's eyes to the potential for flexibility" (Architect \#6), even if their advice was not always taken on board. Any consideration of adaptability was therefore very much driven by practitioners rather than clients ( “... rather than be compliant, how do you make sure they (the client) are thinking beyond themselves for the best possible circumstances?” (Architect \#4).

The second group of clients (Type B) use the terms 'adaptability' and 'flexibility' in design briefs without really understanding or articulating what those terms mean. This ambiguity was cited frequently by interviewees, for instance: “... it's got to be flexible but they don't actually know what they want to get out of that flexibility" (Architect \#1) and “... we were asked to design the buildings to be flexible but we didn't get a specific brief with regards to what that meant in terms of flexibility” (Architect \#7). Another interview recounted how "We got a brief which was simply... a list of terminologies which I didn't understand" (Architect \#8). One of the architects suggested that the word 'adaptability' had become somewhat meaningless because of its frequent but vague usage: “... it’s a bit like sustainability. It's also become a word that's sort of just said" (Architect \#1). He also suggested that vague requests for adaptability or flexibility were a sign of an "uncommitted" client ("I think it's like a safety net really that someone writes in a brief"), a view echoed by another interviewee who 
argued that "The danger of saying that everything is flexible is that you commit to nothing" (Architect \#9). Hence, despite the good intentions of these (Type B) clients, their lack of understanding of adaptability means that, without guidance by their design team or advisors, their needs are either likely to be unfulfilled or they will be provided with the wrong type(s) of adaptability.

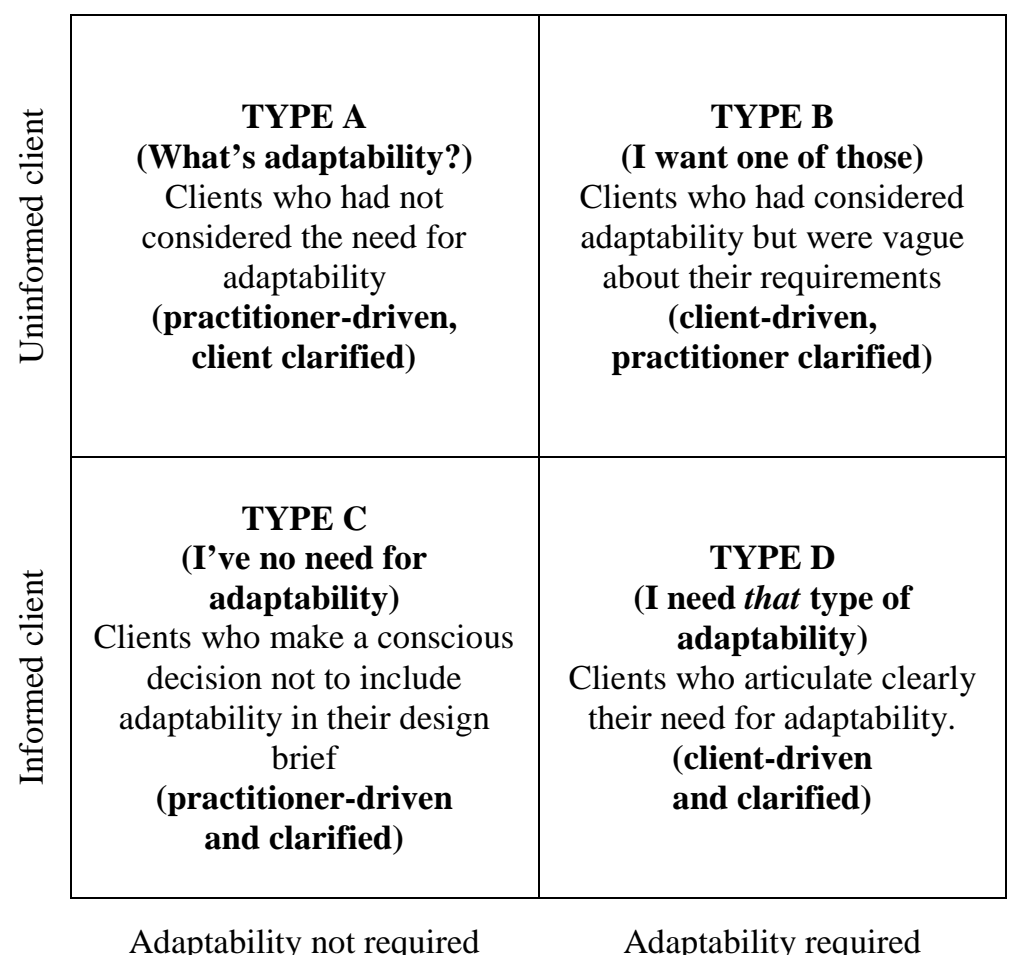

Figure 2: Client archetypes (derived from interviews)

Clients in the third group (Type C) made a conscious decision not to include adaptability in their design briefs, either because they had no long-term interest in their buildings, selling them upon completion, or because they were experienced developers who had found adaptability to be a waste of money. One planning officer (Planner \#1) recalled a conversation with the head of one of the UK's leading housing developers, who said that “...we don't want people adapting their houses anyway, when they have more kids we want 
them to go and buy a new house." The lack of consideration for adaptability amongst Type C clients was seen by some practitioners to be a function of short-term profit motives and/or a disregard for sustainable practices. Motivated designers therefore saw the inclusion of adaptability into their schemes to be akin to a covert operation:

"Sometimes we are trying to get something into a project that the client might not actually want if he knew enough about it. That sounds horrible but you have to almost take that approach sometimes because you can't really have that dialogue with them as a client. Because if you have that dialogue with them they are going to be thinking well is he more interested in somebody else or me? I am paying you to do a service why are you talking to me about somebody else's interest 30 years down the line." (Architect \#10)

This approach speaks volumes about the disconnect that can occur between clients and designers in contemporary building projects. However, it also raises a number of interesting ethical and philosophical questions, particularly in cases where future users or society will benefit from the adaptability, rather than the client who is paying for the construction of the building. In such cases, who should be responsible for safeguarding our built environment and society’s long-term interests: owners, occupiers, designers, contractors or government?

Clients in the fourth group (Type D) were more often than not repeat order clients, such as large corporate occupiers or property developers, whose market knowledge and experience of managing buildings gave them a more informed view of what adaptability means in practical terms. For example:

“... they [the developers] all know their market and they've got their teams of agents who know the market intimately and they know roughly what the market's asking for, so if an office guy says flexibility, he's normally talking about different ways of tenanting the building and I think at the heart of when they say 'flexible', that's what they mean. They mean attractive to lots of different types of tenant" (Architect \#7) 
However, while such clients advocated specific types of adaptability in their buildings, their perspectives on what constitutes adaptability remained quite narrow (sector-based). For example, one interviewee wondered whether “... those very, very simple highly reduced commercial buildings which were built specifically to be flexible will prove to be our undoing in the sense that they are flexible only with regard to a certain type of corporate life" (Architect, \#11).

\section{Conclusions}

Despite suggestions in the literature that the word 'adaptability' is commonly used in the construction industry, there is very little understanding about how practitioners' comprehend adaptability or the terminology that they use when talking about the ability of buildings to accommodate change. This study has therefore addressed a gap in the existing literature, by foregrounding the voices of industry practitioners and exploring their (sometimes very different) interpretations of adaptability in buildings. Although many of the examples reflect the UK bias of the interviewees and that around half of them were architects, we believe the evidence supports five conclusions that could have international ramifications. The first three relate specifically to the themes discussed above (terminology, meaning and briefing) whilst the other two conclusions are drawn from the findings of our research.

1. Terminology - Practitioners collectively have a rich and varied vocabulary when talking about adaptability that results in misalignments between the problem space and the solution.

The findings support the literature, in that an array of language was used to describe adaptability. Very rarely did interviewees say the word 'adaptability'; instead they used a mix of synonyms, antonyms and metaphors. Some of these terms are found in the literature (e.g. flexibility, future-proofing, indeterminacy), while others are not (e.g. resilience, longlife/loose fit, immutable). Such diversity in terminology is interesting but also problematic, 
because words are the means through which people convey abstract ideas to each other (Johns, 1999). Findings from the interviews signified the emergence of two camps - one focused on the use of terminology that reflected adaptability as a solution's ability to employ multiple states (flexibility), the other through their capacity to be 'knocked around' (durability). Developing a common vocabulary is particularly important in building projects, as practitioners from different disciplines and professional backgrounds interact and collaborate with each other to design and construct buildings (Markus and Cameron, 2002).

2. Meaning - The meanings that practitioners attach to adaptability tended to diverge by sector rather than discipline, often reflecting clients' priorities or market norms in a particular sector.

The previously stated distinctions in terminology often exacerbate divergences in meaning. Luck’s (2003, p.533) research suggests that even “... a common vocabulary is not enough to share meaning; the constructs of the dialogue should be similar, demonstrating a level of understanding that extends beyond semantic correctness". In this study we found that adaptability meant different things to different people, with instances of shared meaning reflecting conventions, practices and priorities within particular sectors, rather than 'professional registers' (Orna-Montesinos, 2013). For instance, the notion of being able to accommodate the needs of different tenants was implicit in practitioners' understanding of adaptability in the speculative office and retail sectors. There were several examples of project teams that had worked together on previous developments, a process that had enabled them to "mediate the definition of specific terms through dialogue" (Luck, 2003; p.534). In contrast, practitioners who were new to a project or a particular sector sometimes found the terminology being used unfamiliar or confusing. Hence, despite a general consensus on what adaptability is, the applied meaning of adaptability varied depending on context, leading to differences in the use of terminology amongst stakeholders. 
1. Briefing - The application of adaptability during project briefing unfolded differently depending upon the client's dispositions to the designers.

Language plays a particularly important role during project briefing. The briefing process involves clients communicating their intentions and objectives to designers (Ryd, 2004). Decisions taken during briefing can have costly implications further down the line, during design, construction and operation, so it is critical that clients and designers speak the same language when it comes to adaptability. One of the few studies to examine how adaptability manifests itself in briefing was undertaken in Norway by Arge and Blakstad (2010), but their research only focused on a single case study and was arguably an example of good, rather typical, industry practice. The interviews in this study provided a more extensive insight into this issue, suggesting that while some clients are able to clearly articulate their need for adaptability in projects (Type D clients), others are much less informed and articulate (Type A and B clients). Consequently, if and when the words 'adaptability' and 'flexibility' find their way into design briefs, they tend to be written without a clear understanding of what the concept actually means in practical terms (Type B clients), which in turn can result in inappropriate design solutions.

3. Articulation - Buildings could be made more adaptable by a clearer articulation of adaptability.

There is a general sentiment in the literature that buildings are not designed and constructed to be as adaptable as they could (or perhaps should) be (e.g. see Brand, 1994; Gann and Barlow, 1996), and previous research (Pinder et al., 2013) has explored some of the reasons for this, including the fragmented nature of the building industry, short-term business models (in the case of some Type C clients) and concerns over comprising a building's first use. However, the language used by practitioners, and their different interpretations of adaptability, could also be a barrier to developing more adaptable buildings and achieving 
specific forms of adaptability. Although this issue has been discussed previously (e.g. see Friedman, 2002; Carthey et al., 2011; Pinder et al., 2013), this research has explored the matter in greater depth and suggests that a clearer articulation of the meaning of adaptability during briefing and design can give rise to more appropriate levels of adaptability in the built environment. Hence, greater clarity about the meaning of adaptability may also reduce the likelihood of buildings being designed with unnecessary adaptable features that cost money but are never utilised.

4. Clarification of needs - The level of adaptability required in a building project is usually a combination of specific (internal) needs of a client and the generic (external) needs of the broader property market.

The 'recipe' for achieving adaptability is rarely the same in any two building projects, despite the fact the project teams often fall back on 'ready-made' or 'off-the-shelf' design solutions. Clarifying the internal and external needs for accommodating future change is therefore an important step in providing an appropriate level of adaptability in buildings. Adaptability may have an underlying meaning, focused on spatial reconfiguration (versatility), but often terminology and needs differ across sectors. In addition, meanings diverge to encompass different types of change. Future research should therefore focus on developing methods that can be used to help elicit a clearer articulation of clients' needs with respect to adaptability in buildings and provide a better insight into how requests for adaptability elicited during briefing can be translated into built form (design tactics). The latter could be informed by exploring links between client/user requirements (adaptability types) and the 'sub-elements' (e.g. 'layers' and components) of buildings (e.g. see Brand, 1994).

The findings of this study also have implications for government departments and industry bodies who have an interest in the built environment and influence the way that buildings are designed and constructed in particular sectors, usually through a combination of regulation 
and/or guidance. Current practices of such organisations tend to reinforce some of the problems identified in this research, in that their use of the term 'adaptability' tends to be ambiguous. The authors therefore recommend that such organisations think carefully about how their policies and guidance refer to and promote adaptability in buildings. For example, in the UK professional bodies such as the British Institute of Facilities Management (BIFM), Royal Institute of British Architects (RIBA) and the Royal Institution of Chartered Surveyors (RICS) could issue guidance to help promote a common language across their memberships in an effort to develop a shared understanding of what adaptability means in practice.

\section{Acknowledgements}

This paper is based on research undertaken as part of the Adaptable Futures project at Loughborough University. We would like to acknowledge the financial support of the Engineering and Physical Sciences Research Council and the Innovative Manufacturing and Construction Research Centre at Loughborough University, together with the input and case studies provided by our industry partners. Further information about Adaptable Futures can be found at www.adaptablefutures.com

\section{References}

Addis, W. and Schouten, J. (2004), Principles of design for deconstruction to facilitate reuse and recycling, CIRIA, London.

Arge, K. (2005), “Adaptable office buildings: theory and practice”, Facilities, Vol. 23 No. 3/4, pp. 119-127.

Arge, K. and Blakstad, S. (2010), “Briefing for adaptability”, in Blyth, A. and Worthington, J. (Eds), Managing the brief for better design, 2nd edition, Spon Press, Abingdon, pp. 159-170.

Berger, P. and Luckmann, T. (1966), The social construction of knowledge: a treatise in the sociology of knowledge, Open Road Media, Soho, NY.

Blakstad, S.H., (2001), A Strategic Approach to Adaptability in Office Buildings, Unpublished doctoral dissertation, Norwegian University of Science and Technology, Oslo (NBN: no-2306). 
Blyth, A. and Worthington, J. (2010), Managing the brief for better design, 2nd edition, Spon Press, Abingdon.

Brand, S. (1994) How buildings learn: what happens after they're built, Penguin, New York. Carthey, J., Chow, V., Jung, Y. M. and Mills, S. (2011), “Flexibility: beyond the buzzwordpractical findings from a systematic literature review”, Health Environments Research \& Design Journal, Vol. 4 No. 4, pp. 89-108.

Chandra, V. and Loosemore, M. (2011), “Communicating about organizational culture in the briefing process: case study of a hospital project”, Construction Management and Economics, Vol. 29 No. 3, pp. 223-231.

Dubois, A. and Gadde, L. (2002), "Systematic combining: an abductive approach to case research”, Journal of Business Research, Vol. 55 No. 7, pp. 553-560.

Eisenhardt, K. and Graebner, M. (2007), “Theory building from cases: opportunities and challenges”, Academy of Management Journal, Vol. 50 No. 1, pp. 25-32.

Ellison, L. and Sayce, S. (2007), “Assessing sustainability in the existing commercial property stock: establishing sustainability criteria relevant for the commercial property investment sector”, Property Management, Vol. 25 No. 3, pp. 287-304.

Fischler, R. (1995), “Strategy and history in professional practice: planning as world making”, in Liggett, H. and Perry, D. (eds), Spatial Practices, Sage, London, pp.13-58.

Friedman, A. (2002), The adaptable house: designing homes for change, McGraw-Hill, New York.

Froggatt, K. (1998), “The place of metaphor and language in exploring nurses’ emotional work”, Journal of Advanced Nursing, Vol. 28 No. 2, pp. 332-338.

Gann, D. and Barlow, J. (1996) "Flexibility in building use: the technical feasibility of converting redundant offices into flats”, Construction Management and Economics, Vol. 14 No.1, pp. 55-66.

Groak, S. (1992), The idea of building, 1st edition, E\&FN Spon, London.

Johns, N. (1999), “What is this thing called service?”, European Journal of marketing, Vol. 33 No. 9/10, pp. 958-974.

Leaman, A. and Bordass, B. (2004) “Flexibility and adaptability”, in Macmillan, S., Designing better buildings, Taylor \& Francis, Abingdon, pp. 145-156. 
Leaman, A., Bordass, B. and Cassels, S. (1998), Flexibility and adaptability in buildings: the 'killer' variables, Building Use Studies, London.

Luck, R. (2003), “Dialogue in participatory design”, Design Studies, Vol. 24 No. 6, pp. 523535.

Lynch, K. (1958), “Environmental adaptability”, Journal of the American Institute of Planners, Vol. 24 No. 1, pp.16-24.

Markus, T. and Cameron, D. (2002), The words between the spaces: buildings and language, Routledge, London.

McGregor, W. (1994), “Designing a “Learning Building””, Facilities, Vol. 12 No. 3, pp. 9-13. Morse, J. (1991), “Approaches to qualitative-quantitative methodological triangulation”, Nursing Research, Vol. 40 No. 2, pp. 120-123.

Olander, S. (2007), “Stakeholder impact analysis in construction project management”, Construction Management and Economics, Vol. 25 No. 3, pp. 277-287.

Olsson, N., and Hansen, G. (2010), "Identification of critical factors affecting flexibility in hospital construction projects”, Health Environments Research \& Design Journal, Vol. 3 No. 2, pp. 30-47.

Orna-Montesinos, C. (2013), “Constructing professional discourse: a multiperspective approach to domain-specific discourses”, Ibérica, Vol. 25, pp. 213-236.

Pinder, J., Schmidt, R. and Saker, J. (2013), “Stakeholder perspectives on developing more adaptable buildings”, Construction Management and Economics, Vol. 31 No. 5, pp. 440-459. Pratt, M. (2008), “Fitting oval pegs into round holes: tensions in evaluating and publishing qualitative research in top-tier North American journals”, Organizational Research Methods, Vol. 11 No. 3), pp. 481-509.

Pressler, G. (2006) “Born to flex: flexible design as a function of cost and time”, Health Facility Management, Vol. 9 No. 6, pp. 53-58.

Richards, L. and Morse, J. (2012), Readme first for a user's guide to qualitative methods, Sage Publications, Thousand Oaks.

Russell, P. and Moffatt, S. (2001), Assessing buildings for adaptability, IEA Annex 31 Energy-Related Environmental Impact of Buildings. 
Ryd, N. (2004), “The design brief as carrier of client information during the construction process”, Design Studies, Vol. 25 No. 3, pp. 231-249.

Schiellerup, P. and Gwilliam, J. (2009), “Social production of desirable space: an exploration of the practice and role of property agents in the UK commercial property market”, Environment and Planning C: Government and Policy, Vol. 27 No. 5, pp. 801-814.

Schmidt R., Eguchi, T., Austin, S., and Gibb, A. (2010), "What is the meaning of adaptability in the building industry?”, In proceedings of the 16th International Conference on 'Open and Sustainable Buildings’, CIB 104, Bilbao, Spain, May 2010, pp. 227-236.

Schneider, T. and Till, J. (2005), “Flexible housing: opportunities and limits”, Architectural Research Quarterly, Vol. 9 No. 2, pp. 157-166.

Schneider, T. and Till, J. (2007), Flexible housing, Elsevier, Oxford.

Silverman, D. (2000), “Analyzing talk and text”, in Denzin, N. and Lincoln, Y., Handbook of qualitative research, pp. 821-834.

Strauss, A., and Corbin, J. (1998), Basics of qualitative research: Procedures and techniques for developing grounded theory, Sage, Thousand Oaks, CA.

Weeks, J. (1965), “Hospitals for the 1970s”, Medical Care, Vol. 3 No. 4, pp. 197-203. 